\title{
Review: The Second Norwegian North Polar Expedition
}

\section{Author(s): H. W. F.}

Review by: H. W. F.

Source: The Geographical Journal, Vol. 23, No. 6 (Jun., 1904), pp. 778-780

Published by: geographicalj

Stable URL: http://www.jstor.org/stable/1776502

Accessed: 18-04-2016 10:28 UTC

Your use of the JSTOR archive indicates your acceptance of the Terms \& Conditions of Use, available at

http://about.jstor.org/terms

JSTOR is a not-for-profit service that helps scholars, researchers, and students discover, use, and build upon a wide range of content in a trusted digital archive. We use information technology and tools to increase productivity and facilitate new forms of scholarship. For more information about JSTOR, please contact support@jstor.org.

The Royal Geographical Society (with the Institute of British Geographers), Wiley are collaborating with JSTOR to digitize, preserve and extend access to The Geographical Journal 


\section{Harriman Alaska Expedition.}

'Glaciers and Glaciation.' By G. K. Gilbert. Vol. iii., pp. xii., 231. New York: Doubleday, Page \& Co. 1904.

So many accounts of the glaciers of Alaska have appeared in the last few years from the pens of Canadian and American geologists, that it would seem difficult for the present to write anything about them that is both important and new. Prof. Gilbert has evidently felt this difficulty, for, owing partly to this cause and partly to the shortness of his visit, his actual observations were practically confined to corroborating the statements of other authors and collecting the most recent data regarding the periodical variations of the length of the glaciers. Most of what he has observed has been observed and described before, and, aware of this, he has exercised a laudable brevity in the narrative of his work. But it is in the two concluding chapters of the book, in which he passes on to the general considerations regarding the nature and power of glacial erosion and the geographical development of the Alaskan seaboard, that the interest of the volume centres. He recognizes the existence of an old peneplain, which, after it had been reduced to sea-level, was uplifted to heights of 3000 to 5000 feet and carved into valleys and ridges. Skirting the shores are the remains of lower plains, which are, however, of small importance. The intense glaciation to which the whole area has been subjected in Pleistocene times has produced a typical fiord coast, very similar in all essentials to that of Norway and West Scotland. The debated question of the origin of the fiords is discussed in a masterly fashion, and the conclusion at which the author arrives is, that they are old valleys which bear unmistakable evidence of having been greatly deepened and modified in their contours by ice-erosion. He compares and contrasts the work of running water and of ice in modelling the relief of land surfaces, and comes to the interesting conclusion that, despite all qualifications, the hanging valley is the most important witness yet discovered to the magnitude of the work accomplished by the glaciers of the Pleistocene. The importance of this verdict from so great an authority on physiographical processes cannot fail to be appreciated by all who are interested in the subject.

J. S. F.

\section{POLAR REGIONS.}

\section{The Second Norwegian North Polar Expedition.}

'New Land: Four Years in the Aretic Regions.' By Otto Sverdrup. 'Translated by Ethel Harriet Hearn. London: Longmans. 1904.

Captain Sverdrup's paper, read at the Royal Geographical Society, April 27, was published in the Journal for July, 1903. In that communication Sverdrup gave a summary of the geographical and scientific results of the recent Norwegian Polar Expedition in the Fram,1898-1902. The two volumes now published, with maps and excellent illustrations, give full details of this thoroughly successful Arctic expedition. Its original object was to enter the polar area through Smith sound, to examine the north-west coast of Greenland, and to attempt the circumnavigation of that island-continent. The conditions of the ice in Kane basin during the navigable season of 1898 prevented any advance northward, and the Fram was forced to winter on the north-east shore of Ellesmere Land. Sverdrup was no more fortunate in his attempts to get northward in the following year. After these two unsuccessful endeavours, he abandoned his original project, and, sailing southward, re-passed Smith sound and entered Jones sound. There on the south shore of Ellesmere Land the Fram remained for the next three years. From his ship in Jones sound, as the base of operations, Sverdrup explored the hitherto unknown area that lay between the most north-eastern point reached by Belcher's expedition 
in 1853 , and that gained by Aldrich in 1876, on the north-western coast of Grant Land. The three years of strenuous enterprise passed by Sverdrup and his companions in exploring the wide gap were crowned by the most complete success, and the lately vacant space on our maps is now filled with new lands and islands. The survey of both sides of Jones sound and Cardigan strait; the accurate delineation of the entire west coast of Ellesmere Land, with the examination of its great fiords; the tracing of the south shore of Grant Land to its western extremity; the discovery of a large island, separated from Ellesmere Land by Eureka sound and Nansen sound, named Axel Heiberg Land, after the patron of the expedition; and the finding of two more considerable islands still further to the westward, are valuable additions to geographical knowledge. The explorations of the expedition embrace an approximate area of 100,000 square miles. We may now assume that the outer fringe of the Parry archipelago, from Ireland's Eye of McClintock, to Aldrich's Cape Columbia, has been determined, and it is extremely improbable that any land exists between these islands and the north pole. The " ancient ice, blue and slippery," which Sverdrup describes as pushed up against the western or exposed side of Axel Heiberg Land, with the absence of icebergs, points to the same conclusion.

This "ancient" or "old polar ice with enormously high melted-off ridges and dales," is obviously identical in character with the blue massive floes of extraordinary thickness met with on the northern shores of Grant and Grinnell Lands, and called "palæocrystic" by the Nares Expedition.

Of the small ship's company, sixteen souls in all, that left Norway on board the Fram, four were capable young men of science-a cartographer, a botanist, a zoologist, and a geologist, in addition to the medical officer, who unfortunately died before the end of the first year. The shcrt preliminary reports given by these gentlemen on the geology, botany, zoology and meteorology are valuable additions to our knowledge, but are merely precursors to the fuller information which wili be published when the entire collections have been worked out.

The geological investigations of Herr Schei possess special value, for he is, as far as we are aware, the first trained geologist who has explored in the Parry archipelago. His determination of the rocks from Cape Sabine as far as Norman Lockyer island, which is the limit of his advance northwards, agrees with that of the Nares Expedition. After entering Jones sound the entire field of his investigations is fresh, and his sketch-map shows what an immense area has been examined. His discoveries prove the existence of Archæan rocks in the south of Ellesmere Land, whilst Cambro-silurian, Devonian, and Carboniferous formations occupy extensive areas, but the east side of Heiberg Land and the opposite shore of King Oscar Land, with both sides of the entrance to Greely Fiord are considered by Herr Schei to consist of Mesozoic formations. Tertiary deposits were likewise met with, and they in all probability are the equivalents of the Miocene strata already known to occur in the vicinity of Discovery bay, in Grinnell Land. The phanerogams of the Arctic Regions have been so thoroughly worked that beyond increasing our knowledge of distribution, the botanist of the expedition adds but a few species to the list of flowering plants already recorded from the archipelago, but the immense collections of mosses, seaweeds, fresh-water algæ, lichens, and fungi made by Herr Simmons will be a welcome addition to our knowledge of these lower forms of vegetation. It was hardly to be expected that Herr Bay, in his interesting report, would add greatly to our previous knowledge of the vertebrate fauna of the archipelago, but the examination of the dredgings will doubtless prove of interest and scientific value.

There can be no question that the valuable results of this enterprise, never 
surpassed in its thoroughness and completeness by any previous Arctic expedition, is due to the almost unrivalled experience and admirable qualifications of the leader, and also, in Sverdrup's own words, to those two indispensable adjuncts to the carrying out of polar research, "ski and dogs."

H. W. F.

\section{MATHEMATICAL AND PHYSICAL GEOGRAPHY.}

Volcanoes.

'Der Vulkan: die Natur und das Wesen der Feuerberge.' By Prof. Hippolyte Hass.

Pp. 340. With Plates. Berlin : Alfred Schall. 1904.

In this little book Prof. Hass has given us a succinct and readable account of much theoretical and controversial matter regarding the nature, origin, and mechanism of volcanic action. It is evidently written à propos of the eruptions in Martinique, and is meant for the general reader, but is on the whole more suited to the requirements of the student, who will find in it a summary of recent speculations, most of which have not yet found their way into the text-books. It is illustrated by a few well-chosen plates, and would have certainly been improved by fuller references to the literature of the subject and a more adequate bibliography.

J. S. F.

\section{Plant Geography.}

'A Manual and Dictionary of the Flowering Plants and Ferns.' By J. C. Willis, M.A. Second Edition. Cambridge: University Press. 1904.

This is, perhaps, the most useful botanical manual in existence for the purposes of travellers and others, who, without being professed botanists, are desirous of acquiring some knowledge of the general principles of the morphology, classification, and distribution of plants. Without being overloaded with detail, Part I. brings out with great clearness these broad principles, giving, besides, some useful information on economic plants ; while Part II. consists of an alphabetical dictionary of the principal orders, genera, etc., in which the salient facts regarding each are concisely summarized. 'The chapter on distribution is particularly instructive, from the care taken to explain the life-conditions of plants and their relation to external environment. There are useful hints on collecting plants, though some will be surprised to find so much countenance given to the popular notion that pressure is a principal requisite in the preservation of specimens.

\section{GENERAL.}

French Missions.

'La France au dehors. Les Missions Catholiques Françaises au XIX'e siècle. Publiées sous la direction du Père J. B. Piolet, s.J. 6 vols. Paris: A. Colin. 1902-1903.

In so many quarter's of the globe have French missionaries (even more, perhaps, than those of any other nation) been the earliest pioneers in remote and uncivilized districts, that a general history of the missions carried out by them, such as is presented by the sumptuous work now before us, cannot fail to include much that is of interest, both to the geographer and ethnologist. Although the nineteenth century had not so much to show as some of its predecessors in the way of actual exploring work on the part of the French fathers, their work in many out-of-theway regions, as, e.g., the frontiers of China and Tibet, and a large number of localities in tropical Africa, have added much to the general stock of knowledge about them, though the information collected has not always been readily accessible. The present work possesses an authoritative character, as it is the outcome of the co-operation of all the French Catbolic societies, and it is profusely illustrated by photographs of places, scenery, and native types, some of much interest from the excellent idea they convey of the nature of the countries depicted 